Santa Clara University

Scholar Commons

Political Science

College of Arts \& Sciences

Fall 2008

\title{
The Liberation Hypothesis and Racial and Ethnic Disparities in the Application of California's Three Strikes Law
}

Elsa Y. Chen

Santa Clara University, echen@scu.edu

Follow this and additional works at: http://scholarcommons.scu.edu/poli_sci

Part of the Political Science Commons

\section{Recommended Citation}

Chen, Elsa Y. "The Liberation Hypothesis and Racial and Ethnic Disparities in the Application of California's Three Strikes Law." Journal of Ethnicity in Criminal Justice, Volume 6, Number 2 (Fall 2008), p. 83-102.

This is an Accepted Manuscript of an article published by Taylor \& Francis in Journal of Ethnicity in Criminal Justice in Fall 2008, available online: http://www.tandfonline.com/10.1080/15377930802096462.

This Article is brought to you for free and open access by the College of Arts \& Sciences at Scholar Commons. It has been accepted for inclusion in Political Science by an authorized administrator of Scholar Commons. For more information, please contact rscroggin@scu.edu. 
Running Head: Liberation Hypothesis and CA Three Strikes

\section{The Liberation Hypothesis and Racial and Ethnic Disparities in the Application of California's Three Strikes Law}

Please direct all correspondence to:

Elsa Y. Chen, Ph.D

Assistant Professor

Department of Political Science

Santa Clara University

500 El Camino Real

Santa Clara, CA 95053

(408) 551-7055

echen@scu.edu

Biographical Sketch of Author:

Elsa Y. Chen, PhD is an Assistant Professor in the Department of Political Science at Santa Clara University. Her research focuses primarily on U.S. criminal justice policy, including analysis of sentencing and corrections policy, examination of the sources and extent of racial and ethnic disparities in the criminal justice system, assessment of the role and impacts of prosecutorial discretion, and measurement of the effects of mandatory minimum policies such as “Three Strikes and You're Out" laws. 


\begin{abstract}
This paper examines the extent to which racial and ethnic disparities exist in the implementation of California's “Three Strikes and You're Out” law. The analysis then examines whether racial and ethnic disparities vary by type of offense. Logistic regression analysis of individual-level data on over 171,000 California prison inmates indicates that African-Americans are more likely than whites and Latinos to receive third-strike sentences, even when legally relevant variables are controlled. The analysis also finds that Latino defendants are significantly less likely to receive third-strike sentences. The analysis finds that the black-white gap is greater for offenses known as "wobblers," which can be filed as either felonies or misdemeanors (i.e. offenses for which prosecutors have greater discretion in the charging decision), than for offenses that must always be charged as felonies. Racial disparities are also greater for property and drug offenses than for violent crimes.
\end{abstract}

Keywords: race, sentencing, Three Strikes, prosecutorial discretion 


\section{The Liberation Hypothesis and Racial and Ethnic Disparities in the Application of California's Three Strikes Law ${ }^{1}$}

\section{Introduction, Background, and Hypotheses}

Criminal sentencing laws are usually enacted at the state or national level, but the implementation of most policies takes place at the local level of government. For example, California's "Three Strikes and You're Out" law is implemented in large part by district attorneys and judges, elected county officials whose practices and policies may reflect the attitudes of the constituencies that voted them into office. Mandatory sentencing laws like "Three Strikes" are designed to limit the degree of discretion that decision-makers in the criminal justice system are permitted to exercise. However, some flexibility exists in the law's implementation. Prosecutors can move to dismiss prior convictions that might count as strikes, "in the furtherance of justice." According to the "letter of the law," any offender who has two or more serious or violent "strikes" shall face a mandatory sentence of twenty-five years to life in prison for any subsequent felony conviction regardless of the severity of the current offense, but in some counties, prosecutors do not initiate Three Strikes proceedings unless the new conviction is for a serious or violent offense. Discretion is exercised by prosecutors in the case filing decision: for certain offenses, known as "wobblers," the prosecutor must decide whether to charge the crime as a felony (which, upon conviction, would include a prison term and trigger a second- or third-strike sentence for a defendant with one or more prior serious or violent convictions) or a misdemeanor (which would not). Prosecutors and judges may also reduce prior convictions for "wobbler" offenses from felonies to misdemeanors retroactively, or charge single or multiple counts, one or more of which may be strikes, from a single incident. District Attorneys retain the authority to craft internal policies regarding how the Three Strikes law is 
applied. A central question in the current investigation is whether this discretion is exercised to the advantage or disadvantage of certain racial or ethnic groups.

This paper investigates this question empirically, using a previously unavailable dataset containing individual-level records for over 171,000 inmates in the California prison system. Logistic regression models are designed to measure the extent of racial and ethnic disparity in the Three Strikes sentencing process, when demographic characteristics and legally relevant variables, including conviction offense, prior record, and parole status are held constant. The analysis finds that some, but not all, of the observed racial/ethnic disparities can be explained by these factors, and that African-Americans fare much worse than whites, even when demographic and legal factors are controlled. It is also clear that prosecutorial or judicial discretion is exercised, particularly for less serious offenses. The analysis finds that this disadvantages African-Americans, but it seems to work in Latino and immigrant offenders' favor.

\section{Background on Implementation and Impacts of "Three Strikes" and Mandatory Minimum Sentencing Laws}

In 1994, at the height of a national movement to "get tough on crime," the "Three Strikes and You're Out" law passed in California by ballot initiative with 72 percent public support, and was confirmed by the state legislature. "Three Strikes" has two main components: first, if a defendant has a prior conviction for a serious or violent offense (i.e. a "strike") and is convicted of a subsequent felony, the sentence for the current felony conviction is automatically doubled. This is referred to as the law's "second strike" provision. Second, if a defendant has two or more prior serious or violent felony convictions, as specified in California penal code sections 667.5(c) and 1192.7(c), any subsequent felony conviction carries a mandatory "third-strike" sentence of 25 years to life in prison (Ricciardulli, 2002). ${ }^{2}$ Three Strikes has ardent supporters along with vehement critics, and the latter group includes many who believe that the law is applied 
disproportionately against African-Americans and Latinos (Ehlers, Schiraldi, \& Lotke, 2004; Families to Amend California's Three Strikes, 2006).

Indeed, African-Americans are heavily overrepresented among second- and third-strike inmates. As shown in Table 1, they make up about 35 percent of second-strikers and 45 percent of third-strikers among California prison inmates, despite the fact that African-Americans constitute only slightly more than 6 percent of California's adult population (California Department of Corrections and Rehabilitation, 2005; United States Census Bureau Population Division, 2004). Whites, on the other hand, make up over half of the California adult population but only about one-quarter of second- and third-strike inmates (California Department of Corrections and Rehabilitation, 2005; United States Census Bureau Population Division, 2004).

Relative to their share of the adult population, Latino inmates are overrepresented among second-strike inmates, but underrepresented among third-strikers. However, these patterns of over- and underrepresentation do not necessarily indicate that discrimination is present; they may be due to variation among groups in eligibility for "strikes" sentences. This study investigates the extent to which "legally relevant" variables such as the defendants' offenses and criminal records explain intergroup differences in second- and third-strike sentences, and if not, whether the degree of prosecutorial discretion given to prosecutors is associated with the disparities.

\section{[TABLE 1 ABOUT HERE]}

\section{Theoretical Frameworks: Focal Concerns Theory and Liberation Hypothesis}

The discussion of whether and how race influences sentencing has spanned more than five decades, with substantial inconsistency in both research methods and conclusions, ranging from findings of greater sentence severity for black and Latino defendants to findings of apparent 
leniency towards defendants from the same groups (Albonetti, 1991). Recent work by Steffensmeier, Ulmer, and Kramer (1998) finds that race, gender, and age have both independent and interactive effects on sentencing outcomes, with defendants who are young, black, and male experiencing the most negative outcomes. The authors conclude that judges' sentencing decisions are mostly based on "legally relevant variables" such as offense severity and prior record, but these decisions are also influenced by their assessment of the offenders with regard to three main "focal concerns": "blameworthiness" and harm done to the victim, "dangerousness" of the offender, and "practical constraints and consequences," including a wide range of factors from courtroom workgroup dynamics to "local politics and community norms" (Steffensmeier, Ulmer, \& Kramer, 1998). Steffensmeier and his co-authors suggest that judges' assessments of these focal concerns could be influenced by stereotypes and expectations associated with defendant characteristics such as race, gender, and age, and their empirical findings support this idea.

I hypothesize that similar dynamics influence both Three Strikes sentencing outcomes and, more broadly, felony sentences in California. Not only are race, gender, and age likely to influence judges' decisions, but these factors are also likely to affect charging decisions made by prosecutors. Although both judges and prosecutors have legal authority to exercise discretion in the application of Three Strikes, mandatory sentencing policies tend to shift the power to make sentencing decisions from judges to prosecutors (Greenwood et al., 1998; Kieso, 2005; Miethe, 1987; Misner, 1996; Ricciardulli, 2002; Zimring, Kamin, \& Hawkins, 1999). In Three Strikes cases, prosecutorial discretion is particularly important because the sentence associated with a third-strike charge is extremely long and not negotiable. 
The adoption and implementation of "Three Strikes and You're Out" in California has been described as "the largest penal experiment in American history" (Zimring et al., 1999). This vast sentencing reform provides an unusual opportunity to test leading theories on the use of prosecutorial discretion and the impacts of extralegal factors in the determination of sentencing outcomes. The data collected for this study make it possible to conduct rigorous empirical analyses to support or refute the widely-asserted belief that discretion in the application of Three Strikes is exercised to the disadvantage of certain groups, particularly African Americans or Latinos. Analysis of individual-level data will represent a significant improvement over existing analyses primarily based on aggregate statistics (Ehlers et al., 2004; Kieso, 2005).

\section{Prosecutorial Discretion and Mandatory Minimums}

Mandatory minimum laws like "Three Strikes and You're Out" are clearly intended to restrict the amount of discretion, especially leniency, allowable in the sentencing of repeat offenders. How, then, is it possible for Three Strikes be applied more aggressively against certain defendants? The answer may lie in the "wiggle room" that remains for prosecutorial and judicial discretion in the law's application.

"In the furtherance of justice," a prosecuting attorney may file a motion to dismiss one or more prior convictions that would otherwise count as strikes, thus sparing a defendant the mandatory third-strike sentence of 25 years to life if convicted (Legislative Analyst's Office, 2005). ${ }^{3}$ District Attorneys, who are county-level elected officials in California, retain the legal authority to determine guidelines and policies regarding the circumstances under which attorneys in their offices charge eligible cases as third strikes or petition the court to waive prior offenses (Bowers, 2001; California Legislative Analyst's Office, 2005; Olson, 2000). Discretion may also be exercised by prosecutors or judges to charge certain offenses known as "wobblers" as either 
felonies (which trigger Three Strikes) or misdemeanors (which, in sharp contrast, carry a maximum sentence of one year in jail), or to charge multiple counts, including strikes, from a single incident (Legislative Analyst's Office, 2005; Ricciardulli, 2002).

\section{Liberation Hypothesis and Sentencing Disparities for Different Offense Types}

There are numerous reasons to believe that racial and ethnic sentencing disparities may be greater for certain criminal offenses than for others. Several criminal justice researchers have found that minorities are overarrested at higher rates for less serious nonviolent offenses than for serious or violent crimes, and that disproportionalities are greatest for drug offenses, including those associated with the "War on Drugs," where there is more subjectivity in the process of searching or arresting suspects or filing charges (Barnes \& Kingsnorth, 1996; Beckett, Nysop, \& Pfingst, 2006; Blumstein, 1983, 1993; Klein, Petersilia, \& Turner, 1990; Miller, 1996; Petersilia, 1983; Tonry, 1995). According to the "liberation hypothesis," originally set forth by Kalven and Zeisel (1966), jurors in a criminal trial are more likely to deviate from the facts of a case, and therefore allow their decisions to be influenced by personal opinions or values, when the evidence against the defendant is less conclusive, i.e. when they are "liberated" from legal constraints such as convincing eyewitness testimony, a recovered firearm, clear injury to the victim, extreme heinousness of the offense, or similar factors that, if present, would reduce ambiguity regarding the appropriate verdict (Kalven \& Zeisel, 1966; Reskin \& Visher, 1986; Spohn \& Cederblom, 1991; Walker, Spohn, \& DeLone, 1996). Penalties are relatively clearly defined for serious and violent offenses, but for lesser crimes, less consensus exists regarding appropriate levels of punishment; therefore there is more potential for juror discretion, which may include consideration of "legally irrelevant factors such as race" (Spohn \& Cederblom, 1991; Walker et al., 1996). "Wobblers," discussed above, fall into the latter category of crimes 
due to the considerable legal latitude involved in the process of filing charges. In their 1991 study using data from Michigan, Spohn and Cederblom found that black defendants were sentenced more harshly than whites for assault, but not for more serious offenses such as murder, robbery, and rape. This paper seeks to examine whether the same dynamic holds true in California, even under a mandatory minimum policy like Three Strikes, which presumably limits flexibility, and might therefore leave less room for arbitrariness or discrimination in sentencing.

\section{Summary of Hypotheses}

In light of the background, theory, and hypotheses presented above, this investigation seeks to test the following hypotheses:

- H1: Because they are associated with certain "focal concerns," demographic characteristics of defendants, such as race, ethnicity, age, and gender, are likely to influence Three Strikes sentencing outcomes. The analysis will examine whether the effects of these factors on Three Strikes sentences consistent with those found in previous studies of sentencing, such as those by Steffensmeier and his colleagues (Demuth \& Steffensmeier, 2004; Steffensmeier et al., 1998). Because a defendant's demographic traits play a role in the assessment of "focal concerns," I hypothesize that observed racial and ethnic disparities in third-strikes sentences will be reduced, but not entirely eliminated, when "legally relevant" control variables, such as prior record and offense severity, are introduced in the analysis.

- $\mathbf{H}_{2}$ : The liberation hypothesis predicts that disparities will vary by offense, with defendants' extralegal characteristics more likely to influence charging decisions for offenses whose penalties are less clearly agreed-upon. Racial and ethnic minorities may therefore be more likely than whites to be charged as felons for "wobblers" (i.e. crimes 
which may be charged as either felonies or misdemeanors). By the same token, there will also be greater observed disparity between racial and ethnic groups in Three Strikes sentencing for non-violent offenders than for violent offenders.

\section{Data and Methods}

\section{Offender-level Data}

The analysis is conducted on data obtained by special request from the California Department of Corrections and Rehabilitation (CDCR) in September 2006. The first dataset includes individual-level records for all 171,163 felony offenders housed in the California prison system on August 31, 2006. The following variables are included in each record:

- Defendant's race

- Ethnicity (Hispanic origin)

- Sex

- Age

- Commitment county

- Current offense(s)

- Probation or parole status

- Sentence length

- 2-strikes or 3-strikes sentence

The CDCR dataset has some limitations. It includes inmates who received a prison sentence, but not those who received jail terms, probation, drug treatment, or other alternative sentences. Because of this, it does not include records for defendants whose "wobbler" offenses were charged as misdemeanors, or those charged with felonies who were not convicted. Data on dropped or reduced charges, which have been found to be important and sometimes to vary by race (Adams \& Cutshall, 1987; Albonetti, 1987, 1992), are not available from this source. To my knowledge, there is no centralized database available to the public that contains a large sample of individual-level cases from arrest through sentencing in California. These data would 
have to be obtained from the courts or created by matching police arrest files to court records and inmate files; this is outside the scope of this study.

\section{Wobblers and Non-wobblers}

The data include the records for "wobbler" offenders who were charged with felonies, convicted, and sent to prison. Of the 532 separate offense codes included in the dataset, 143 are "wobblers," meaning that the prescribed penalty under California's sentencing guidelines includes either a prison term or an alternate sentence of a jail term, a fine, or a combination of the two (Judicial Council of California, 2007). As discussed above, the charging decision for these types of offenses is significant, because the decision to file a "wobbler" as a misdemeanor rather than as a felony can spare a defendant with one or more prior serious or violent convictions either the mandatory doubled second-strike sentence or the mandatory third-strike sentence of 25 years to life in prison. Offenses that do not fall under the "wobbler" description are referred to in this paper as "non-wobblers;" these crimes must be always charged as felonies, and therefore will always lead to second- or third-strikes sentences for eligible offenders upon conviction. The offense codes in the dataset have been coded as wobblers or non-wobblers, based on the sentences prescribed in the California Penal Code, Health and Safety Code, Business and Professions Code, Vehicle Code, Welfare and Revenue Code, Harbor and Navigations Code, Insurance Code, Revenue and Taxation Code, Government Code, Civil Code, or Corporations Code. All of the inmates whose records are in the dataset were convicted of felonies. Thirty-two percent of the inmates were sent to prison after being convicted of a wobbler offense charged as a felony rather than as a misdemeanor; the remaining sixty-eight percent were sentenced for non-wobblers.

\section{Methods}


The preliminary analyses reported in this paper employ logistic models with a dummy variable representing the presence or absence of a third-strike sentence as the primary dependent variable. The primary independent variables of interest are the dummy variables associated with the mutually exclusive race/ethnicity categories, African-American, Hispanic/Latino, white, Asian, American Indian, and "other." Other demographic variables included in the model include those representing gender, immigrant status, and age (six categories). Control variables include parole status (dummy variables representing new offense, parole violation, and parole hearing pending), offense type (thirty-six mutually exclusive categories), number of prior serious offenses, and number of prior violent offenses. Selected summary statistics are presented in Table 2 below.

\section{[TABLE 2 ABOUT HERE]}

As shown in Table 2 above, counties are categorized and coded based on the type of internal policy (if any) the District Attorney has implemented regarding the treatment of secondand third-strikes eligible cases. An indicator representing county-level policy is constructed using information gathered from interviews with representatives from the local District Attorneys' offices, examination of position papers or public statements published in the print media, other publications, or online sources, and interviews with representatives from County Public Defenders' offices if no information can be obtained from the DA. This step tests the hypothesis that extralegal factors such as a defendant's race or ethnicity will have greater influence on the assessment of "focal concerns" by prosecutors in jurisdictions that permit the highest degree of prosecutorial discretion. 


\section{Findings and Discussion}

Table 3 below compares the results of two logistic regression models. The first model includes several demographic measures: race/ethnicity, immigrant status, sex, and age. Trial county is also included. This model produces statistically significant odds ratio estimates indicating that African-Americans have 1.85 times greater odds of receiving third strike sentences than whites, and American Indians have 1.42 times higher odds of receiving third strike sentences than whites. Individuals born outside the United States have significantly lower odds of receiving third strike sentences than native-born offenders (odds ratio $=0.63$ ). Men face much higher odds than women of receiving Three Strikes sentences, with an odds ratio of 9.25 attached to the dummy variable for Male.

Adding a set of legally relevant variables to the model - number of serious and violent prior convictions, parole status, and offense category (36 categories coded as dummy variables, not displayed in Table 3) - greatly enhances the explanatory power of the model, with the rsquared value increasing from 0.09 to 0.31 . Not surprisingly, all of these additional variables, which represent the factors that are supposed to be considered in the sentencing process, are highly statistically significant $(\mathrm{p}<0.001)$. In addition, the inclusion of legally relevant variables reduces the observed racial/ethnic disparities, shrinking the odds ratio associated with Black from 1.85 to 1.47 . The odds ratio associated with American Indian decreases only slightly, from 1.42 to 1.40 , and the ratio associated with immigrant status moves closer to 1 . The odds ratio for Latino ethnicity is slightly less than 1 in both models, and it is significant when the legally relevant variables are controlled. The Male odds ratio falls substantially with the legally relevant controls, but men still face 5.05 times higher odds than women of being sentenced under Three Strikes. The "immigrant effect" is also tempered, with the associated odds ratio increasing from 
0.63 to 0.76 . Although the odds ratios associated with several demographic traits grow smaller when legally relevant factors are controlled, it is notable that they remain significant, and in many cases, substantial in size.

These findings confirm the first hypothesis, which predicted that demographic characteristics would exert an influence on Three Strikes sentencing even with legally relevant variables controlled, due to the role of these characteristics in the assessment of "focal concerns" by decision-makers in the criminal justice system, such as prosecutors, judges, or juries. However, it is interesting to observe that Latinos and members of other minority groups do not appear to experience the same consistent disadvantage with regard to sentencing that AfricanAmericans do, and immigrants seem to receive consistently lighter sentences than native-born offenders.

\section{[TABLE 3 ABOUT HERE]}

Table 4 below displays the results of a test of Hypothesis 2. Two logistic regression models are estimated, using separate subsets of the data. The analysis is performed first on the cases for which the current conviction was for a "wobbler" offense, and then on the "nonwobbler" cases. The results show that the disparity between African-Americans and whites in Three Strikes sentencing is greater for wobbler offenses (odds ratio $=1.56$ ) than it is for nonwobbler offenses (odds ratio $=1.44$ ). Furthermore, there appears to be disparity in favor of Latinos when their offenses are wobblers (odds ratio $=0.76$ ), but there is no statistically significant difference in odds between Latinos and whites for non-wobblers. In contrast, the interaction term representing Latino*immigrant has an odds ratio of 1.56 and is significant at $\mathrm{p}<$ 0.05 in the wobblers model, but is closer to 1 and not statistically significant in the non-wobblers 
model. The odds ratios associated with the American Indian dummy variable are close in magnitude to those for African-Americans, but significant only in the non-wobbler analysis. Like the analyses shown in Table 3, these analyses show that men have about 5 times higher odds than women of receiving Three Strikes sentences; this is the case regardless of whether the current conviction is for a wobbler or non-wobbler.

These findings are consistent with Hypothesis 2, which predicts that sentencing disparities will be greater for offenses whose associated penalties are less clearly defined (e.g. wobblers), than for offenses for which there is more consensus regarding appropriate punishments (e.g. non-wobblers).

\section{[TABLE 4 ABOUT HERE]}

To further test Hypothesis 2, another set of models is compared. Table 5 below displays the results of three separate logistic regression models, run on subsets of the data according to offense type: violent, property, or drug.

The liberation hypothesis would predict that racial and ethnic disparities in sentencing would be greater for less serious offenses (i.e. property and drug crimes) than for violent offenses, and the results of the analysis are consistent with this prediction. The odds ratio associated with the dummy variable Black is 1.35 in the violent offender analysis, but higher 1.76 and 1.52 , respectively - in the property and drug offender analyses. This finding is similar to those of Spohn and Cederblom (1991). Consistent with the findings of the analyses summarized in the previous two tables, an apparent disparity in favor of Latinos is present (odds ratio $=0.86)$ and statistically significant in the violent offender analysis. However, the odds ratio is closer to 1 and not significant in analyses of the property and drug offender subsets. This runs counter to the hypothesis that racial/ethnic disparities (in either the positive or negative direction) 
will be greatest for the least severe offenses. The findings for Latinos born outside the United States are more consistent with the liberation hypothesis. The odds ratio on the Latino*Immigrant interaction term are greatest and statistically significant in the property crime model (odds ratio $=1.66, \mathrm{p}<0.05$ ), but closer to 1 and not significant in the other two models . The odds ratio associated with the variable Male remains consistent (ranging from 5.11 to 5.32) and significant $(\mathrm{p}<.001)$ in the models for all three crime categories.

\section{Conclusions and Policy Implications}

The preceding analyses tested a set of hypotheses based on focal concerns theory and the liberation hypothesis. Consistent with the findings of prior investigations of sentencing disparities, the analysis indicates that disparities in Three Strikes sentencing outcomes are present, even when several key legally relevant variables are controlled. African-American offenders appear to be significantly more likely than whites to receive third-strike sentences, even when the nature of the offense, the defendant's prior record, and parole status are controlled. The same is true for American Indians. The disparity between male and female offenders in Three Strikes sentencing is even greater than that between blacks and whites. This is likely a result of the assessment of "focal concerns" such as "dangerousness" of the offender (female felons may be considered less of a threat to society than male felons), "practical constraints and consequences" such as limited capacity in women's correctional facilities or concerns about finding appropriate caregivers for the women's custodial children, or "blameworthiness," especially for women who may have been provoked or abused

(Steffensmeier, Kramer, \& Streifel, 1993; Steffensmeier et al., 1998). 
A notable and perhaps unexpected finding is that Latino offenders experience sentencing disparities, but to their advantage rather than disadvantage. Where significant effects were detected for immigrant status, these were also in the form of lower odds of a Three Strikes sentence. These observations may indicate leniency in the sentencing of Latinos and foreignborn defendants. An alternative explanation is that substantial portions of these groups are deported either before or after they are convicted, leaving fewer repeat offenders in the prison population. While the explanation merits further examination, one important conclusion to draw from these findings is that African-Americans and Latinos do not experience the same disadvantage in the sentencing process; therefore, it is instructive to look beyond a black-andwhite typology when studying the role of race and ethnicity in the justice system.

The liberation hypothesis receives support from the outcomes of the analyses. Disparities between blacks and whites are found to be wider in the sentencing of wobbler offenses than for non-wobblers, and the black-white sentencing gap is also greater for property or drug offenses than for violent crimes. These findings are consistent with those of past studies indicating that extralegal factors are more likely to influence juries when the offense in question is less serious. In the case of Three Strikes, the implications of a third-strike sentence for a wobbler are enormous. A wobbler charged as a misdemeanor will receive a sentence of one year in jail or less, and the standard, non-strikes sentence for most wobbler offenses is about 24 months in prison, which would be doubled to 48 months for a second-striker. However, a third-strike wobbler conviction carries a mandatory 25 -to-life prison term. Thus, the presence of inappropriate disparities in Three Strikes sentencing for cases like these is especially disturbing.

Perhaps the most controversial aspect of Three Strikes has been the eligibility of nonviolent offenders for mandatory prison terms of 25 years to life under the law. Critics of 
Three Strikes argue that the law's inclusion of all felons with "strikes," rather than a narrow class of offenders, violates the legal principle of proportionality for crimes and punishments (Kieso, 2005; Zimring, Hawkins, \& Kamin, 2001). The analyses above indicate that a different form of injustice may be present in the law's application towards nonviolent criminals: it is among property and drug offenders that the greatest disparities between black and white offenders are observed. This finding is consistent with the liberation hypothesis.

Even in the application of a mandatory minimum sentencing policy in a determinate sentencing state, racial sentencing disparities appear to persist. In California, the Three Strikes law still does appear to be disproportionately applied against African-American defendants. To the extent that disparities in sentencing outcomes result from decisions made, consciously or unintentionally, by participants and authorities in the criminal justice system, it may be possible to mitigate or prevent discriminatory applications of the law. Determination of the extent of the problem and potential points for intervention may lead to closer examination of policies and practices in certain agencies, which could in turn result in improved efforts to ensure fairness in the administration of laws like Three Strikes. The reduction of racial disparities in sentencing policies could have enormous effects on the lives of sentenced individuals and their families, as well as the communities from which black inmates originate and to which most of them will eventually return. In a society where black men face a 29 percent chance of incarceration during their lifetime, more black male dropouts are imprisoned than employed, and 7 percent of all African-American children have an incarcerated parent (Bonczar \& Beck, 1997; Travis \& Petersilia, 2001), progress in the understanding, reduction, and prevention of sentencing disparities between African-Americans and whites is long overdue. 


\section{NOTES}

${ }^{1}$ The author wishes to thank Alexander Friedman for research assistance and the Santa Clara University Faculty-Student Research Assistant Program for support for this project.

${ }^{2}$ Laws called "Three Strikes and You're Out" also exist in twenty-three other states and at the federal level, but they are considerably narrower in scope, application, cost, and societal impact than California's law; all three offenses must be serious or violent felonies in order to qualify for Three Strikes sentencing in most jurisdictions other than California (Clark, Austin, \& Henry, 1997).

${ }^{3}$ A California Supreme Court ruling in the 1996 case People v. Superior Court (Romero) determined that judges could exercise the same discretion, though some legal scholars have concluded that this power has seldom been exercised (Ricciardulli, 2002; Vitiello, 1997a, 1997b).

${ }^{4}$ Sources: State population data from United States Census Bureau Population Division (2005), Table 4: Estimates of the Population by Race and Hispanic or Latino Origin for the United States and States: July 1, 2005; all other statistics in this table calculated using August 31, 2006 inmate population data provided by the CA Department of Corrections and Rehabilitation.

\section{REFERENCES}

Adams, K., \& Cutshall, C. R. (1987). Refusing to prosecute minor offenses: The relative influence of legal and extralegal factors. Justice Quarterly, 4(4), 595-609.

Albonetti, C. A. (1987). Prosecutorial Discretion: The Effects of Uncertainty. Law \& Society Review, 21(2), 291-314.

Albonetti, C. A. (1991). An Integration of Theories to Explain Judicial Discretion. Social Problems, 38(2), 247-266.

Albonetti, C. A. (1992). Charge Reduction: An Analysis of Prosecutorial Discretion in Burglary and Robbery Cases. Journal of Quantitative Criminology, 8(3), 317-333.

Barnes, C. W., \& Kingsnorth, R. (1996). Race, Drugs, and Criminal Sentencing: Hidden Effects of the Criminal Law. Journal of Criminal Justice, 24(1), 39-56.

Beckett, K., Nysop, K., \& Pfingst, L. (2006). Race, Drugs, and Policing: Understanding Disparities in Drug Delivery Arrests. Criminology, 44(1), 105-137.

Blumstein, A. (1983). Prisons: Population, Capacity, and Alternatives. In J. Q. Wilson (Ed.), Crime and Public Policy. San Francisco: ICS Press. 
Blumstein, A. (1993). Racial Disproportionality of U.S. Prisons Revisited. University of Colorado Law Review, 64, 743-760.

Bonczar, T. P., \& Beck, A. J. (1997). Lifetime Likelihood of Going to State or Federal Prison. Washington, DC: U.S. Department of Justice, Office of Justice Programs, Bureau of Justice Statistics.

Bowers, J. E. (2001). The Integrity of the Game is Everything: The Problem of Geographic Disparity in Three Strikes. New York University Law Review, 76(4), 1164-1203.

California Department of Corrections and Rehabilitation. (2005). Second and Third Strikers in the Institution Population, June 30, 2005. Sacramento, CA: California Department of Corrections and Rehabilitation, Offender Information Services, Estimates and Statistical Analysis Section, Data Analysis Unit.

California Legislative Analyst's Office. (2005). A Primer: Three Strikes: The Impact After More than a Decade. Sacramento, CA: Legislative Analyst's Office.

Clark, J., Austin, J., \& Henry, D. A. (1997). "Three Strikes and You're Out": A Review of State Legislation. Washington DC: National Institute of Justice.

Demuth, S., \& Steffensmeier, D. (2004). Ethnicity Effects on Sentence Outcomes in Large Urban Courts: Comparisons Among White, Black, and Hispanic Defendants. Social Science Quarterly, 85(4), 994-1011.

Ehlers, S., Schiraldi, V., \& Lotke, E. (2004). Racial Divide: An Examination of the Impact of California's Three Strikes Law on African-Americans and Latinos. Washington, DC: Justice Policy Institute.

Families to Amend California's Three Strikes. (2006). 3-Strikes is Applied Disproportionately to Minorities, Poor and Particular Counties. Retrieved March 8, 2006, from http://www.facts1.com/reasons/minor.htm\#racial

Greenwood, P., Everingham, S., Chen, E., Abrahamse, A. F., Merritt, N., \& Chiesa, J. (1998). Three Strikes Revisited: An Early Assessment of Implementation and Effects (No. NCJRS Report Number 194106). Santa Monica: RAND.

Judicial Council of California, A. O. o. t. C. (2007). CJER Felony Sentencing Handbook. Oakland, CA: Continuing Education of the Bar, California.

Kalven, H., \& Zeisel, H. (1966). The American Jury. Boston: Little.

Kieso, D. W. (2005). Unjust sentencing and the California Three Strikes law. New York: LFB Scholarly Pub.

Klein, S., Petersilia, J., \& Turner, S. (1990). Race and Imprisonment Decisions in California. Science, 247(4944), 812-816. 
Legislative Analyst's Office. (2005). A Primer: Three Strikes: The Impact After More than a Decade. Sacramento, CA: Legislative Analyst's Office.

Miethe, T. D. (1987). Charging and Plea Bargaining Practices under Determinate Sentencing: An Investigation of the Hydraulic Displacement of Discretion. The Journal of Criminal Law and Criminology, 78(1), 155-176.

Miller, J. G. (1996). Search and Destroy: African-American Males in the Criminal Justice System. Cambridge: Cambridge University Press.

Misner, R. L. (1996). Recasting Prosecutorial Discretion. Journal of Criminal Law and Criminology, 86(3), 717-777.

Olson, T. M. (2000). Strike One Ready for More? The Consequences of Plea Bargaining 'First Strike' Offenders under California's 'Three Strikes' Law. California Western Law Review, 36(2), 545.

Petersilia, J. (1983). Racial Disparities in the Criminal Justice System. Santa Monica, CA: Rand.

Reskin, B. F., \& Visher, C. A. (1986). The Impacts of Evidence and Extralegal Factors in Jurors' Decisions. Law \& Society Review, 20(3), 423-438.

Ricciardulli, A. (2002). The Broken Safety Valve: Judicial Discretion's Failure to Ameliorate Punishment Under California's Three Strikes Law. Duquesne Law Review, 41(1), 1-67.

Spohn, C., \& Cederblom, J. (1991). Race and Disparities in Sentencing: A Test of the Liberation Hypothesis. Justice Quarterly, 8(3), 305 - 327.

Steffensmeier, D., Kramer, J., \& Streifel, C. (1993). Gender and Imprisonment Decisions. Criminology, 31(3), 411-446.

Steffensmeier, D., Ulmer, J., \& Kramer, J. (1998). The Interaction of Race, Gender, and Age in Criminal Sentencing: The Punishment Cost of Being Young, Black, and Male. Criminology, 36(4), 763-798.

Tonry, M. H. (1995). Malign Neglect: Race, Crime, and Punishment in America. New York: Oxford University Press.

Travis, J., \& Petersilia, J. (2001). Reentry Reconsidered: A New Look at an Old Question. Crime and Delinquency, 47(3), 291-313.

United States Census Bureau Population Division. (2004, Release Date: September 30, 2004). Table 4: Annual Estimates of the Population by Race Alone and Hispanic or Latino Origin for the United States and States: July 1, 2003 (SC-EST2003-04). Retrieved January 11, 2005, from http://www.census.gov/popest/states/asrh/tables/SC-EST200304.xls 
Vitiello, M. (1997a). Three Strikes and the Romero Case: The Supreme Court Restores Democracy. Loyola of Los Angeles Law Review, 30, 1643-1708.

Vitiello, M. (1997b). Three Strikes: Can We Return to Rationality? Journal of Criminal Law \& Criminology, 87(2), 395-481.

Walker, S., Spohn, C., \& DeLone, M. (1996). The Color of Justice: Race, Ethnicity, and Crime in America. Belmont [Calif.]: Wadsworth Pub. Co.

Zimring, F. E., Hawkins, G., \& Kamin, S. (2001). Punishment and Democracy: Three Strikes and You're Out in California. Oxford: Oxford University Press.

Zimring, F. E., Kamin, S., \& Hawkins, G. (1999). Crime and Punishment in California: The Impact of Three Strikes and You're Out. Berkeley, CA: Institute of Governmental Studies Press. 
Table 1: Racial Composition of California Population, Prison Inmates, and "Strikers"4

\begin{tabular}{lrrrrrr}
\hline & White & Black & Latino & $\begin{array}{r}\text { Asian \& } \\
\text { Pacific } \\
\text { Islander }\end{array}$ & $\begin{array}{r}\text { American } \\
\text { Indian }\end{array}$ & $\begin{array}{r}\text { Other } \\
\text { Race }\end{array}$ \\
\hline \% of CA population & 43.8 & 6.2 & 35.2 & 12.3 & 0.5 & 2.0 \\
\% of all inmates & 27.7 & 28.7 & 38.2 & 1.0 & 0.9 & 3.6 \\
\% of 2nd strikers & 25.8 & 34.3 & 35.7 & 0.7 & 0.8 & 2.6 \\
\% of 3rd strikers & 25.1 & 44.4 & 26.7 & 0.5 & 0.9 & 2.3 \\
\hline
\end{tabular}


Table 2: CDCR Dataset Summary Statistics

\begin{tabular}{llr}
\hline & & Percent \\
\hline Race/Ethnicity & Asian & 0.96 \\
& Black/African-American & 28.7 \\
& Hispanic/Latino & 38.2 \\
& American Indian & 0.95 \\
& Other & 3.6 \\
& White & 27.7 \\
\hline Place of Birth & United States & 83.6 \\
& Outside the U.S. & 16.4 \\
\hline Gender & Male & 93.3 \\
& Female & 6.7 \\
\hline Age & 14 to 24 & 26.8 \\
& 25 to 34 & 33.6 \\
& 35 to 44 & 26.0 \\
& 45 to 54 & 11.0 \\
& 55 to 64 & 2.1 \\
& 65 and up & 0.4 \\
\hline Current Parole & Admission & 62.9 \\
Return Status & Parole violator with new term & 24.8 \\
& Parole violator - return to custody & 9.0 \\
& Pending revocation & 3.3 \\
\hline Offense & Violent & 50.3 \\
Category & Property & 21.3 \\
(General) & Drug & 20.6 \\
& Other & 7.7 \\
\hline Offense Type & Non-wobbler & 67.9 \\
& Wobbler & 32.1 \\
\hline Highest & None & 73.2 \\
Strike Count & 2 Strikes & 21.7 \\
\hline N & 3 Strikes & 171 \\
\hline & & 163 \\
\hline & & \\
& &
\end{tabular}


Table 4: Comparison of Outcomes for Wobblers and Non-Wobblers DV = Three-Strikes Sentence

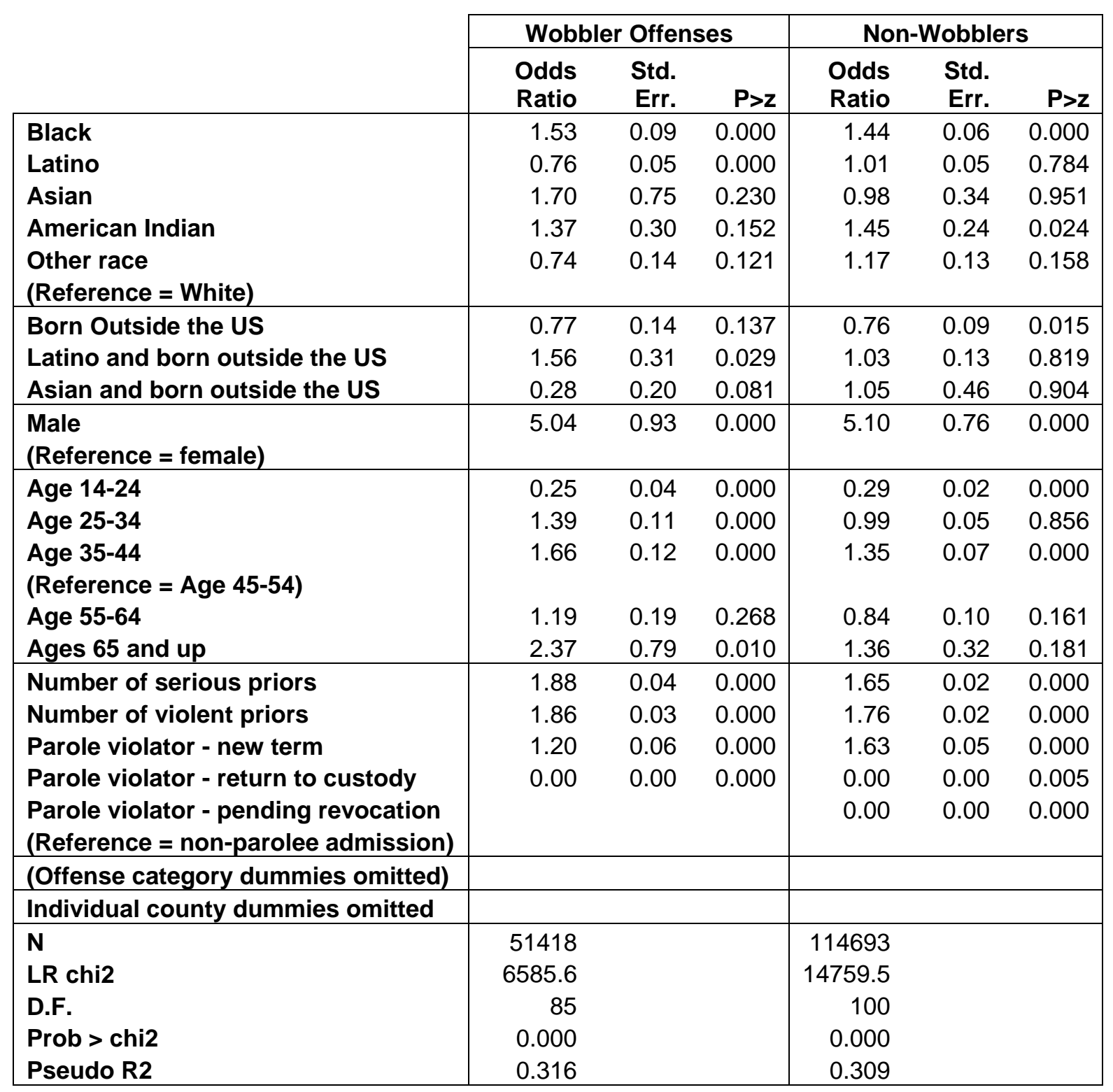


Table 3: Logistic Model with and without Legally Relevant Variables Dependent Variable $=$ Three-Strikes Sentence

\begin{tabular}{|c|c|c|c|c|c|c|}
\hline & \multirow{2}{*}{\multicolumn{3}{|c|}{$\begin{array}{c}\text { Without Legally Relevant } \\
\text { Vars }\end{array}$}} & \multirow{2}{*}{\multicolumn{3}{|c|}{$\begin{array}{c}\text { With Legally Relevant } \\
\text { Vars }\end{array}$}} \\
\hline & & & & & & \\
\hline & $\begin{array}{l}\text { Odds } \\
\text { Ratio }\end{array}$ & Std. Err. & $P>z$ & $\begin{array}{l}\text { Odds } \\
\text { Ratio }\end{array}$ & $\begin{array}{l}\text { Std. } \\
\text { Err. }\end{array}$ & $P>Z$ \\
\hline Black & 1.85 & 0.055 & 0.000 & 1.47 & 0.051 & 0.000 \\
\hline Latino & 0.98 & 0.034 & 0.503 & 0.93 & 0.036 & 0.048 \\
\hline Asian & 1.00 & 0.252 & 1.000 & 1.16 & 0.318 & 0.579 \\
\hline American Indian & 1.42 & 0.168 & 0.003 & 1.40 & 0.183 & 0.011 \\
\hline $\begin{array}{l}\text { Other race } \\
\text { (Reference = White) }\end{array}$ & 1.05 & 0.092 & 0.558 & 1.04 & 0.101 & 0.675 \\
\hline Born Outside the US & 0.63 & 0.053 & 0.000 & 0.76 & 0.073 & 0.005 \\
\hline Latino and born outside the US & 0.97 & 0.094 & 0.728 & 1.15 & 0.125 & 0.196 \\
\hline $\begin{array}{l}\text { Asian and born outside the US } \\
\text { (Reference = US-born) }\end{array}$ & 1.01 & 0.331 & 0.975 & 0.76 & 0.276 & 0.456 \\
\hline $\begin{array}{l}\text { Male } \\
\text { (Reference = female) }\end{array}$ & 9.25 & 1.015 & 0.000 & 5.05 & 0.587 & 0.000 \\
\hline Age 14-24 & 0.16 & 0.009 & 0.000 & 0.30 & 0.019 & 0.000 \\
\hline Age 25-34 & 0.89 & 0.032 & 0.001 & 1.11 & 0.049 & 0.015 \\
\hline $\begin{array}{l}\text { Age 35-44 } \\
\text { (Reference = Age 45-54) }\end{array}$ & 1.45 & 0.051 & 0.000 & 1.45 & 0.061 & 0.000 \\
\hline Age 55-64 & 0.84 & 0.068 & 0.033 & 0.96 & 0.093 & 0.689 \\
\hline Ages 65 and up & 1.03 & 0.170 & 0.869 & 1.58 & 0.297 & 0.016 \\
\hline Number of serious priors & & & & 1.73 & 0.018 & 0.000 \\
\hline Number of violent priors & & & & 1.80 & 0.017 & 0.000 \\
\hline Parole violator - new term & & & & 1.45 & 0.039 & 0.000 \\
\hline Parole violator - return to custody & & & & 0.00 & 0.000 & 0.000 \\
\hline $\begin{array}{l}\text { Parole violator - pending revocation } \\
\text { (Reference = non-parolee admission) }\end{array}$ & & & & 0.00 & 0.001 & 0.000 \\
\hline \multicolumn{7}{|l|}{ (Offense category dummies omitted) } \\
\hline \multicolumn{7}{|l|}{ (County dummies omitted) } \\
\hline $\mathbf{N}$ & 170861 & & & 169553 & & \\
\hline LR chi2 & 6266.2 & & & 21328.8 & & \\
\hline D.F. & 66 & & & 105 & & \\
\hline Prob > chi2 & 0.000 & & & 0.000 & & \\
\hline Pseudo R2 & 0.091 & & & 0.309 & & \\
\hline
\end{tabular}


Table 5: Comparison of Outcomes by Offense Group; DV = Three-Strikes Sentence

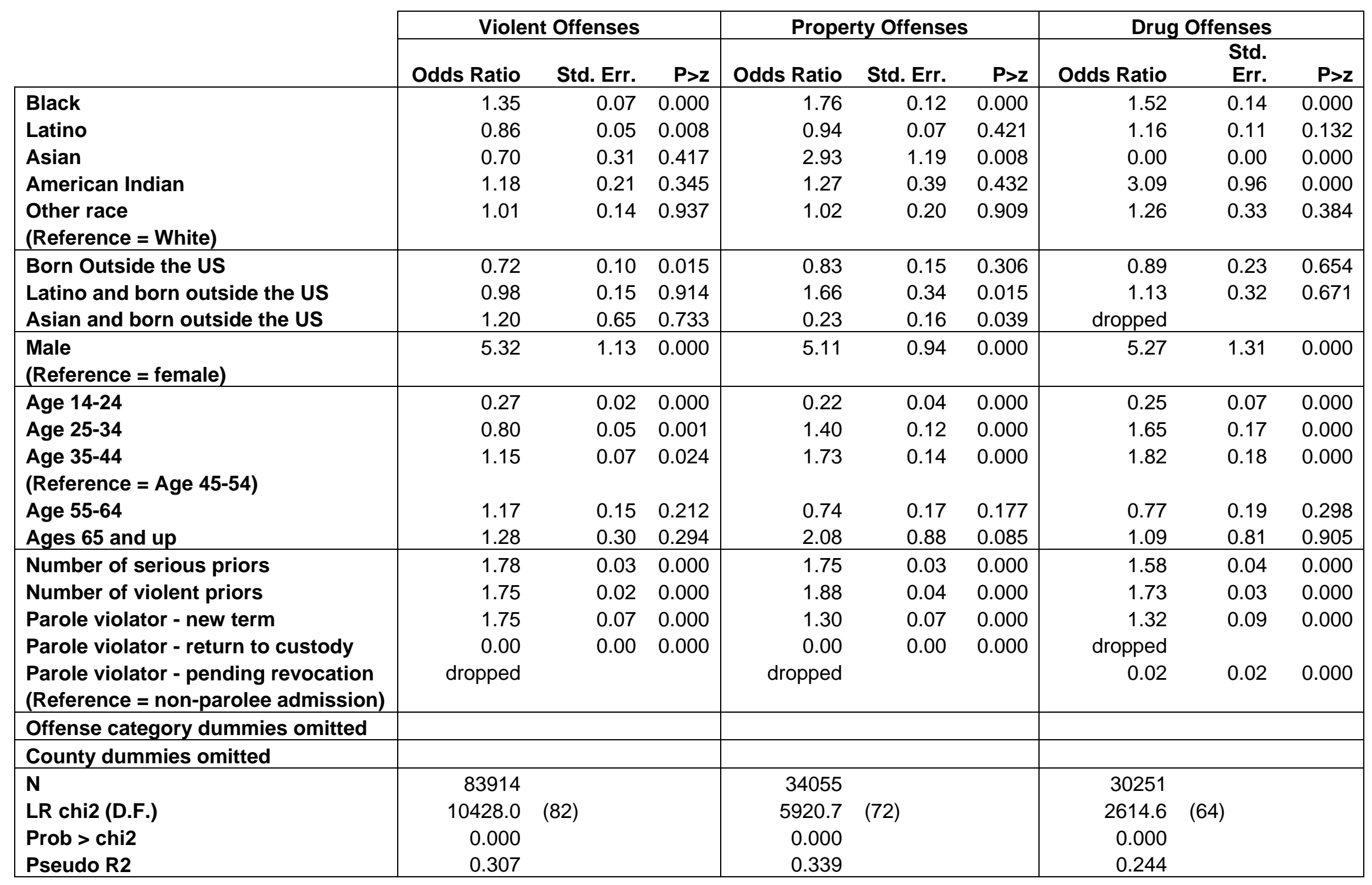

